\title{
ASSOCIATIONS BETWEEN IODINE INTAKE, URINARY IODINE EXCRETION, AND LEARNING ACHIEVEMENT AMONG ELEMENTARY STUDENTS AGED 6-12 YEARS
}

\author{
Romiza Arika1), Sapja Anantanyu²), Yulia Lanti Retno Dewi3) \\ ${ }^{1)}$ Masters Program in Nutrition, Universitas Sebelas Maret \\ ${ }^{2)}$ Doctoral Program in Community Development and Empowerment, \\ Universitas Sebelas Maret \\ 3)Faculty of Medicine, Universitas Sebelas Maret
}

\begin{abstract}
Background: Iodine is an essential micronutrient needed for the production of thyroid hormone. Thyroid hormone supports various physiological functions for normal growth and is particularly critical for cognitive and neurodevelopment during fetal life, infancy, and childhood. This study aimed to examine the associations between iodine intake, urinary iodine excretion (UIE), and learning achievement among elementary students aged 6-12 years.

Subjects and Method: A cross sectional study was conducted at 4 elementary schools in Pakis, from March to April 2019. A sample of 117 elementary school students was selected by random sampling. The dependent variable was learning achievement in math and Indonesian test scores. The independent variables were iodine intake and UIE. The data were collected by questionnaire and analyzed by a multiple linear regression.

Results: Math test scores was positively associated with iodine intake $(b=1.40 ; 95 \%$ $\mathrm{CI}=0.01$ to $0.03 ; \mathrm{p}=0.014)$ and UIE $(\mathrm{b}=1.30 ; 95 \% \mathrm{CI}=0.01$ to $0.02 ; \mathrm{p}=0.001)$. Indonesian test score was positively associated with iodine intake $(\mathrm{b}=1.90 ; 95 \% \mathrm{CI}=0.01$ to $0.03 ; p=0.002)$ and UIE $(b=8.00 ; 95 \% \mathrm{CI}=0.04$ to $0.10 ; \mathrm{p}=0.037)$.

Conclusion: Iodine intake and UIE increase math and Indonesian language learning achievement in elementary students aged 6-12 years.
\end{abstract}

Keywords: iodine intake, urinary iodine excretion, learning achievement

\section{Correspondence:}

Romiza Arika. Masters Program in Nutrition, Universitas Sebelas Maret, Jl. Ir. Sutami 36A, Surakarta 57126, Central Java. Email: romizaarika652@gmail.com. Mobile: +6289506237763. 